\title{
Neurocysticercosis is still prevalent in Mexico
}

\author{
Agnès Fleury, MD, PhD, ${ }^{(1,2)}$ Edda Sciutto, PhD, (I) Carlos Larralde MD, PhD.(I)
}

\section{Fleury A, Sciutto E, Larralde C. Neurocysticercosis is still prevalent in Mexico. Salud Publica Mex 2012;54:632-636.}

\begin{abstract}
In this work, we report the published cases of human and porcine cysticercosis, as well as Taenia solium taeniasis diagnosed in Mexico during the last 10 years. Numerical data allow us to state that this disease remains as a public health problem in our country. Whereas efficient tools have been developed for the diagnosis and prevention of cysticercosis, we strongly recommend further measures allowing the control and eventual eradication of this parasite in Mexico.
\end{abstract}

Key words: epidemiology; Taenia solium; neurocysticercosis; Mexico
Fleury A, Sciutto E, Larralde C.

La neurocisticercosis es aún prevalente en México.

Salud Publica Mex 2012;54:632-636.

\section{Resumen}

En este trabajo reportamos los casos publicados de cisticercosis humana y porcina, así como de teniosis por Taenia solium diagnosticados en México en los últimos 10 años. Los datos numéricos nos permiten sostener que esta parasitosis continúa siendo un problema de salud pública en nuestro país. Considerando que se han desarrollado herramientas eficientes para el diagnóstico y la prevención de la cisticercosis, recomendamos enfáticamente seguir promoviendo las medidas que permitan el control y posterior erradicación de esta parasitosis en México.

Palabras clave: neurocisticercosis; epidemiología; México
$T^{a}$ aeniasis and cysticercosis are endemic in most of latin America, Asia and Africa countries. ${ }^{1}$ However, the burden of this endemic disease is not easy to appraise due to some characteristics of the infection, namely: 1) human infection with the adult form of the parasite (taeniasis) is mostly asymptomatic; 2) a large proportion of the humans infected by the larvae (cysticercus) are also asymptomatic; 3) taeniasis diagnosis relies on laboratory techniques not routinely made, and 4) accurate diagnosis of human neurocisticercosis (NC) requires costly neuro-radiological studies not available to the whole population at risk. The scarcity and/ or uncertainty of the epidemiological data on teaniasis and cysticercosis have raised some debate and led to unsound conclusions.

Herein, we review and summarize the published studies reporting Taenia solium infections in humans and pigs in Mexico during the last decade.

(I) Instituto de Investigaciones Biomédicas, Universidad Nacional Autónoma de México. México DF, México.

(2) Instituto Nacional de Neurología y Neurocirugía (INNN). México DF, México. 


\section{Methodology}

In this study, a PubMed revision of the papers published in the last ten years containing data on Taenia solium taeniasis and on human or porcine cysticercosis in Mexico is presented. Different combinations of the following key words were used: "Taenia solium, cysticercosis, epidemiology, epilepsy, Mexico". In this review we included only those publications in which: 1) the diagnostic criteria were clearly defined; 2 ) NC diagnosis was made between 2000 and 2010, or, (since in many publications date of diagnosis is not cited) either vesicular (viable) or colloidal (inflammatory) parasites were included between 2000 and 2010. The articles published within these years but without information for dating the diagnosis of human or porcine cysticercosis or for dating the period of inclusion of the patients and the evolution stage of the parasites were not included.

\section{Results}

Table I presents the results found in the PubMed database. ${ }^{2-19}$ As can be seen, several studies demonstrate the persistence of human and porcine T. solium cysticercosis in Mexico. We did not find any publication about the diagnosis of intestinal T. solium tapeworm carriers.

\section{Discussion}

There is no doubt that epidemiological transition is ongoing in Mexico, as shown by the increasing incidence of metabolic, neoplastic and degenerative diseases. ${ }^{20}$ Nonetheless, this trend gives no good reason for disregarding the persistence of infectious diseases in Mexico, mainly those linked with poverty.

Data presented in table I illustrates that the Taenia solium life-cycle is still present in Mexico: up to $32 \%$ of porcine cysticercosis prevalence in some communities and about 500 cases of human NC were diagnosed and reported in the last ten years. Although it is evident that these data are incomplete and do not represent the real burden of human NC and porcine cysticercosis in Mexico, since only a small proportion of the cysticercotic cases are published, these data are sufficient evidence that Taenia solium is still a public health problem in Mexico.

In one recent paper, mainly based on the results of official statistics on human NC morbidity, the opposite conclusion was reached. ${ }^{21}$ The divergence between the evidence herein shown and those published could be due to differences in the accuracy of NC diagnosis. Most of the studies shown in table I came from medi- cal institutions in which NC diagnosis was made using modern radiological technology; in contrast, no information in this respect is given in official statistics, and probably, diagnostic is performed by procedures not equally qualified. Differences in the reliability of the data source could also be involved. According to the official statistics, approximately 400 new NC cases were reported throughout Mexico in 2004. In clear contrast, 120 new NC cases were reported in only one neurological institution (INNN) this same years. ${ }^{12}$ It appears unlikely that a single institution concentrated $25 \%$ of all national NC cases in one year, especially considering the huge differences in sample sizes. Indeed, official statistics come from the entire population of Mexico (circa $112 \times 10^{6}$ inhabitants), while INNN data include only few thousands of Mexican adults. Such a disproportion points to a possible significant under-registration of NC in the nationwide sample, which occurs even though NC notification is mandatory. ${ }^{22}$ The clinical heterogeneity of $\mathrm{NC}$, and the lack of access by a large part of the Mexican population to neuroradiological studies, indispensable for accurate NC diagnosis, could contribute to the nationwide NC under-diagnosis. Such hypothesis is further strengthened by the results of the two CT scan epidemiological studies performed in rural communities of central Mexico, which reported that 9 to $10 \%$ of apparently healthy residents had cranial CT scan images compatible with $\mathrm{NC}^{15,16}$ (table I).

Some considerations about the appropriateness of whether considering a parasitic disease as a "public health problem" or not have to be mentioned. "Public Health" is "the science and art of preventing disease, prolonging life and promoting health through the organized efforts and informed choices of society, organizations, public and private, communities and individuals". ${ }^{23}$ Based on this definition, a public health problem can be defined as a problem which occurs frequently and widely, causes severe disability and suffering, may be effectively dealt with, and treated by ways and means acceptable to patients, their families, and society. Undoubtedly, NC satisfies the three latter points, as it may cause severe disability and suffering, ${ }^{24,25}$ there are effective methods for dealing with it, ${ }^{19,26-28}$ and current treatments are acceptable to all involved..$^{29}$ The issue here is the first point: ¿What is the frequency of NC in Mexico? Data in table I does not answer the question with an acceptable level of precision, but this question can be substituted by: What is the number of NC cases which public health authorities may consider as an "acceptable" proof that NC still merits their attention? In this respect, table I confirms that the absolute number of NC cases is costly in terms of suffering for stricken 


\section{Table I}

\section{Epidemiological studies on taeniasis/cysticercosis in MeXico}

\begin{tabular}{|c|c|c|c|c|c|}
\hline Reference & Place of the study & Type of study & $\begin{array}{l}\text { Diagnosis based on } \\
\text { (serology, radiology) }\end{array}$ & $\begin{array}{c}\text { Number of } \\
\text { subject included }\end{array}$ & $\begin{array}{l}\text { Number } \\
\text { of cases }\end{array}$ \\
\hline \multicolumn{6}{|l|}{ Human studies } \\
\hline \multicolumn{6}{|l|}{ Hospital cases } \\
\hline Cohn-Zurita et al., $2006^{2}$ & México DF (CMN Siglo XXI) & Case-report & $M R I^{*}$ & $N A^{\ddagger}$ & I \\
\hline Chavarria et al., $2006^{3}$ & México DF, (INNN) & $\begin{array}{l}\text { Case-series; diagnosed between } \\
2000-2003\end{array}$ & MRI & $\mathrm{NA}$ & $23^{8}$ \\
\hline Ortiz-Trejo et al., $2006^{4}$ & $\begin{array}{l}\text { Zacatecas (Public general } \\
\text { Hospital) }\end{array}$ & $\begin{array}{l}\text { Case-series; diagnosed between } \\
\text { January and September } 2004\end{array}$ & CT scan & NA & 85 \\
\hline $\begin{array}{l}\text { Alvarado-Esquivel et al., } \\
2008^{5}\end{array}$ & $\begin{array}{l}\text { Durango (Psychiatric } \\
\text { Hospital) }\end{array}$ & Sample of psychiatric patients & $\begin{array}{c}\text { Serology, ELISA } \\
\text { and WB }\end{array}$ & 105 & $\begin{array}{l}8 \text { (ELISA) } \\
\text { I (EITB) }\end{array}$ \\
\hline $\begin{array}{l}\text { Jimenez-Vazquez and } \\
\text { Nagore, } 2008^{6}\end{array}$ & $\begin{array}{l}\text { Morelia, Michoacan (Public } \\
\text { general Hospital) }\end{array}$ & Case-report of vesicular NC & MRI & NA & I \\
\hline $\begin{array}{l}\text { Jimenez-Vazquez and } \\
\text { Nagore, } 2008^{7}\end{array}$ & $\begin{array}{l}\text { Morelia, Michoacan (Public } \\
\text { general Hospital) }\end{array}$ & Case report of vesicular NC & MRI & NA & I \\
\hline $\begin{array}{l}\text { Rio de la Loza and Meza, } \\
2008^{8}\end{array}$ & Hermosillo, Sonora & Case-report of colloidal parasites & MRI & NA & $\mathrm{I}$ \\
\hline Gongora et al., $2008^{9}$ & México DF, (INNN) & $\begin{array}{l}\text { Case-series of vesicular parasites } \\
\text { included between } 2000-2003\end{array}$ & MRI & NA & $31^{\&}$ \\
\hline $\begin{array}{l}\text { Torres-Corzo et al., } \\
2009^{10}\end{array}$ & $\begin{array}{l}\text { San-Luis Potosi (Central } \\
\text { Hospital) }\end{array}$ & $\begin{array}{l}\text { Case-series of neuro-endoscopies } \\
\text { made between I/2003 and 6/2006 }\end{array}$ & MRI & NA & 25 \\
\hline Suastegui et al., 2009"I & $\begin{array}{l}\text { I0 different Mexican } \\
\text { epileptic centers }\end{array}$ & $\begin{array}{l}\text { Samples of late-onset epileptic } \\
\text { patients (debut in } 2000 \text { or after) }\end{array}$ & CT scan & 455 & 96 \\
\hline Fleury et al., $2010^{12}$ & México DF, (INNN) & $\begin{array}{l}\text { All NC patients diagnosed at } \\
\text { INNN in } 2004\end{array}$ & CT scan +/- MRI & 4706 & 120 \\
\hline Cárdenas et al., 201 ${ }^{13}$ & México DF, (INNN) & Case-report & MRI & NA & $\mathrm{I}$ \\
\hline Cárdenas et al., 2012 $2^{14}$ & México DF, (INNN) & $\begin{array}{l}\text { Case-series; diagnosed between } \\
8 / 2005 \text { and } 10 / 2007\end{array}$ & MRI & NA & 50 \\
\hline \multicolumn{6}{|l|}{ Population based studies } \\
\hline Fleury et al., $2003^{15}$ & Tepetzintla, Puebla & Population-based, made in 2001 & CT scan & 154 & 14 \\
\hline Fleury et al., $2006^{16}$ & Cuentepec, Morelos & Population-based, made in 2003 & CT scan & 649 & 59 \\
\hline \multicolumn{6}{|l|}{ Swine-cysticercosis studies } \\
\hline Morales et al., $2002^{17}$ & Cuentepec, Morelos & Sample of pigs & Tongue inspection & 1300 & 429 \\
\hline Morales et al., $2006^{18}$ & State of Morelos & Sample of pigs & Tongue inspection & 1747 & 249 \\
\hline $\begin{array}{l}\text { Morales et al., } 2008^{19} \\
\text { * Magnetic Resonance Imaging } \\
\ddagger \text { Not appropriate } \\
\text { \& It is possible that some patient }\end{array}$ & Sierra de Huautla, Morelos & Sample of pigs & Tongue inspection & 562 & 75 \\
\hline
\end{tabular}

individuals and of resources for public health institutions in Mexico. On this same matter, it is interesting to note the attitude taken by the authors of a recent paper, in which the $78 \mathrm{NC}$ cases acquired inside the United States between 1954 and 2005 were reported. ${ }^{30}$ The authors comment: "Several factors, including the severe, potentially fatal, nature of cysticercosis; its fecal-oral route of transmission; the considerable economic effect; the availability of a sensitive and specific serologic test for infection by adult Taenia solium tapeworms; and the demonstrated ability to find a probable source of infection among contacts, all provide a compelling rationale for implementation of public health control efforts". The differences between these US authors' proposal with some Mexican voices claiming "NC is no longer a public health problem in Mexico" 21 are striking, as the number of NC cases in Mexico is much greater than in this country.

It must also be noted that, as shown in table I, the social conditions allowing the parasite to complete its 
life cycle persist in rural areas of Mexico, and porcine cysticercosis is prevalent in such areas, ${ }^{19,31}$ while, to our knowledge, no cases of porcine cysticercosis have been reported in the United States of America.

Finally, a recent report from the WHO Expert Consultation on Foodborne Trematode Infections and Taeniasis / Cysticercosis ${ }^{32}$ is in accord with our view, stating: "Cysticercosis is endemic in much of Latin America, with "hot spots" of the disease in Mexico (e.g. Yucatan, Guanajuato, Guerrero, Morelos, Puebla), several Central American countries, such as Guatemala, Honduras and Nicaragua, the Andean countries of Bolivia, Ecuador and Peru (e.g. Tumbes), Colombia, Venezuela and northern Brazil", and also that "Neurocysticercosis is a significant public health problem in the entire region, while porcine cysticercosis is a constraint to food security and a major cause of income loss".

$\mathrm{NC}$, as other infectious diseases, is still an embarrassing health problem of Mexico since it is clearly related to the poverty prevailing in under-developed countries.

It is not gratuitous to reflect more deeply on the possible causes of the persistence of Taenia solium infection in Mexico. As it is well known, completion of the life cycle of Taenia solium is clearly related with underdevelopment, as it requires of outdoor defecation and free roaming pigs. As reported by Flisser \& Correa, ${ }^{21}$ global indices of Mexican national development have improved in recent years, posing the question as to why does T. solium transmission cycle still prevail in Mexico. This is probably due to the fact that global indices of national development are not appropriate descriptors of all sectors in Mexico, where extreme social and economic disparities subsist. As table $\mathrm{II}^{33}$ shows, Mexican population income is quite disparate among deciles. Indeed, total current income can be divided in three parts, one of them corresponding to $10 \%$ of the population in Mexico, the richest one; the other one corresponding to $30 \%$ of the population, the middle class, and the third one to $60 \%$ of the population, the poor in Mexico. Such

Table II

Distribution OF THE TOTAL CURRENT INCOME (THREE MONTHS' AVERAGE) IN DECILES OF HOUSEHOLDS (PERCENTAGE) $)^{18}$

\begin{tabular}{lrrrr} 
Deciles & 2002 & 2004 & 2006 & 2008 \\
Deciles I to VI & 27.0 & 26.9 & 27.6 & 26.7 \\
\hline Deciles VII to IX & 37.4 & 36.9 & 36.7 & 37.0 \\
\hline Decile X & 35.6 & 36.2 & 35.7 & 36.3 \\
\hline Total & 100.0 & 100.0 & 100.0 & 100.0
\end{tabular}

an unequal distribution of the national income lasts since 2002 to 2008 at least, without a significant tendency to improve with time. The social disparity among Mexican inhabitants is also clear when comparing the income in rural community population (less than 2500 inhabitants) versus the income of urban population (more than 2500 inhabitants). As shown in table III, ${ }^{33}$ mean income per person grew only by $1.4 \%$ in rural areas whilst $10.8 \%$ in urban areas between 2002 and 2008. These data clearly illustrate that, although global socio-economic indices of Mexico show a positive tendency within these years, a significant part of its population $(60 \%)$-the poor and the rural of Mexico- are not included in the mentioned improvement, and it is in these areas where Taenia solium life-cycle finds conditions to persist.

\section{Conclusion}

All these data and arguments indicate to the persistence of Taenia solium transmission in Mexico at levels which are-to our mind-still too high. Consequently, Mexican health authorities must continue to consider $\mathrm{NC}$ as a public health problem, and the available measures for its control have to be applied in order to prevent and control this disease.

\section{Acknowledgement}

This article was partly supported by Consejo Nacional de Ciencia y Tecnología (CONACYT), project number 2008-86527, 106154, and by CYTED program (Red 211RT0432). The funders had no role in study design, data collection and analysis, decision to publish, or preparation of the manuscript.

Declaration of conflict of interests. The authors declare that they have no conflict of interests.

Table III

TOtAl CURRENT INCOME (THREE MONTHS' AVERAGE) PER HOUSEHOLD AND ITS VARIATION, ACCORDING TO COMMUNITY SIZE, 2002-2008 ${ }^{18}$

\begin{tabular}{|c|c|c|c|c|}
\hline \multirow{4}{*}{ Year } & \multicolumn{4}{|c|}{ Size of the community } \\
\hline & \multicolumn{2}{|c|}{ With 2500 or more inhabitants } & \multicolumn{2}{|c|}{ With less than 2500 inhabitant } \\
\hline & Households & Average & Households & Average \\
\hline & & Income* & & Income* \\
\hline 2002 & 18759449 & 37312 & 5772182 & 18019 \\
\hline 2004 & 19809869 & 38431 & $575 I 578$ & $18|7|$ \\
\hline 2006 & 20685257 & $4 \mid 677$ & 5856070 & 21834 \\
\hline 2008 & 21345884 & $4|34|$ & 5386710 & 18276 \\
\hline \multicolumn{5}{|c|}{ * Mexican pesos } \\
\hline
\end{tabular}




\section{References}

I. Sotelo J. Clinical manifestations, diagnosis, and treatment of neurocysticercosis. Curr Neurol Neurosci Rep 201 I; I 1:529-535.

2. Cohn-Zurita F, Guinto-Balanzar G, Pérez-Cerdán H. Neurocysticercosis associated with pituitary adenoma. Case report and literature review. Cir Cir. 2006;74:47-49.

3. Chavarría A, Fleury A, Bobes RJ, Morales J, Fragoso G, Sciutto E. A depressed peripheral cellular immune response is related to symptomatic neurocysticercosis. Microbes Infect 2006;8: 1082-1089.

4. Ortiz-Trejo JM, Correa-Chacón AJ, Sctelo-Ham El, Torres-Valenzuela

A, Alvarado-Esquivel C. Risk factors associated with neurocysticercosis in a public hospital in Mexico. Gac Med Mex 2006; 142:175-179.

5. Alvarado-Esquivel C, Arreola-Valenzuela MA, Rodríguez-Briones A, Alanís-Quiñones OP, Estrada-Martínez S, Luevanos-Becerra C, et al. Seroprevalence of selected viral, bacterial and parasitic infections among inpatients of a public psychiatric hospital of Mexico. Rev Inst Med Trop Sao Paulo 2008:50:161-164.

6. Jimenez-Vazquez $\mathrm{OH}, \mathrm{Nagore} \mathrm{N}$. Cisternal neurocysticercosis. $\mathrm{Br}$ J Neurosurg 2008;22:774-775.

7. Jimenez-Vazquez $\mathrm{OH}, \mathrm{Nagore} \mathrm{N}$. Role of neuroendoscopy in the treatment of large viable cysticerci in the brain parenchyma. $\mathrm{Br} J$ Neurosurg 2008;22:682-683.

8. Río de la Loza LJ, Meza EL. Cysticercotic encephalitis: case report of miliary infestation in an encephalopathic fashion. Arch Neurol 2008;65:276-277.

9. Góngora-Rivera F, Soto-Hernández JL, Guevara P, Sotelo-Morales J. In neurocysticercosis, CSF cytokines correlate with cerebral blood flow velocities. Neurology 2008;71: I I 19-1 I 22.

10. Torres-Corzo JG, Tapia-Pérez JH, Sánchez-Aguilar M, Della Vecchia RR, Chalita Williams JC, Cerda-Gutiérrez R. Comparison of cerebrospinal fluid obtained by ventricular endoscopy and by lumbar puncture in patients with hydrocephalus secondary to neurocysticercosis. Surg Neurol 2009;71:376-379.

I I. Suástegui R, Gutiérrez J, Ramos R, Bouchan S, Navarrete H, Ruiz J, et al. Clinical characteristics of the late-onset epilepsy in Mexico to the beginning of the new millennium: 455 cases. Rev Invest Clin 2009;61:354-363. I2. Fleury A, Moreno-García J, Valdez-Aguerrebere P, de Sayve-Durán M, Becerril-Rodríguez P, Larralde C, et al. Neurocysticercosis, a persisting health problem in Mexico. PLoSNegl Trop Dis 2010;4:e805.

13. Cardenas G, Bahena A, Soto-Hernandez JL, Fleury A. A dramatic case of intraventricular cysticercosis. Arch Neurol 201 I;68:828-829.

14. Cárdenas G, Valdez R, Sáenz B, Bottasso O, Fragoso G, Sciutto E, et al. Impact of Taenia solium neurocysticercosis upon endocrine status and its relation with immuno-inflammatory parameters. Int J Parasitol 2012;42:17I-176.

I5. Fleury A, Gómez T, Alvarez I, Meza D, Huerta M, Chavarria A, et al. High prevalence of calcified silent neurocysticercosis in a rural village of Mexico. Neuroepidemiology 2003;22:139-145.

16. Fleury A, Morales J, Bobes RJ, Dumas M, Yánez O, Piña J, et al. An Epidemiological study of familial neurocysticercosis in an endemic Mexican community. Trans R Soc Trop Med Hyg 2006;100: 551-558.

17. Morales J, Velasco T, Tovar V, Fragoso G, Fleury A, Beltrán C, et al. Castration and pregnancy of rural pigs significantly increase the prevalence of naturally acquired Taenia solium cysticercosis. Vet Parasitol $2002 ; 108: 4 \mid-48$
18. Morales J, Martínez J], García-Castella J, Peña N, Maza V, Villalobos $\mathrm{N}$, et al. Taenia solium: the complex interactions of biological, social, geographical and commercial factors, involved in the transmission dynamics of pig cysticercosis in highly endemic areas. Ann Trop Med Parasitol 2006; 100:123-135.

19. Morales J, Martínez J], Manoutcharian K, Hernández M, Fleury A, Gevorkian G, et al. Inexpensive anti-cysticercosis vaccine: S3Pvac expressed in heat inactivated MI3 filamentous phage proves effective against naturally acquired Taenia solium porcine cysticercosis. Vaccine 2008;26: 2899-2905.

20. Stevens G, Dias RH, Thomas KJ, Rivera JA, Carvalho N, Barquera S, et al. Characterizing the epidemiological transition in Mexico: national and subnational burden of diseases, injuries, and risk factors. PLoS Med 2008:5:eI 25.

2I. Flisser A, Correa D. Neurocysticercosis may no longer be a public health problem in Mexico. PLoS Negl Trop Dis 2010;4: e83।.

22. Secretaría de Salud. Modificación a la Norma Oficial Mexicana NOM02I-SSA2-1994, para la prevención y control del complejo teniosis/ cisticercosis en el primer nivel de atención médica. Diario Oficial de la Federación, 2004. [consultado $201 \mathrm{I}$ agosto]. Disponible en: http://www. salud.gob.mx/unidades/cdi/nom/m02 Issa294.html.

23. Winslow CE A. The Untilled Fields of Public Health.Science 1920;5I:23.

24. Fleury A, Carrillo-Mezo R, Flisser A, Sciutto E, Corona T. Subarachnoid basal neurocysticercosis: a focus on the most severe form of the disease. Expert Rev Anti infect Ther 201 I;9:123-133.

25. Bhattarai R, Budke CM, Carabin H, Proaño JV, Flores-Rivera J, Corona T, et al. Quality of Life in Patients with Neurocysticercosis in Mexico. Am J Trop Med Hyg 20I I;84:782-786.

26. Del Brutto OH, Roos KL, Coffey CS, García HH. Meta-analysis: Cysticidal drugs for neurocysticercosis: albendazole and praziquantel. Ann Intern Med 2006; | 45:43-51.

27. Assana E, Kyngdon CT, Gauci CG, Geerts S, Dorny P, De Deken R, et al. Elimination of Taenia solium transmission to pigs in a field trial of the TSOLI8 vaccine in Cameroon. Int J Parasitol 2010;40:5 I5-5I9. 28. Cai X, Yuan G, Zheng Y, Luo X, Zhang S, Ding J, et al. Effective production and purification of the glycosylated TSOLI8 antigen, which is protective against pig cysticercosis. Infect Immun 2008;76:767-770. 29. Jung H, Cárdenas G, Sciutto E, Fleury A. Medical Treatment for Neurocysticercosis: Drugs, Indications and Perspectives. Curr Top Med Chem 2008:8:424-433.

30. Sorvillo F, Wilkins P, Shafir S, Eberhard M. Public Health Implications of Cysticercosis Acquired in The United States. Emerg Infect Dis 2011;17:I-6.

3I. Morales J, De Aluja A, Martinez J], Hernandez M, Rosas G, Villalobos $\mathrm{N}$, et al. Recombinant S3Pvac-phage anticysticercosis vaccine; Simultaneous protection against cysticercosis and hydatid disease in rural pigs. Vet Parasitol 20I I; 176: 53-58.

32. World Health Organization. WHO Expert Consultation on Foodborne Trematode Infections and Taeniasis/Cysticercosis. 20II, Geneva, Switzerland: WHO, 20II: 59.

33. Instituto Nacional de Estadística y Geografía. Encuesta Nacional de Ingresos y Gastos de los Hogares (ENIGH). 2008 [consultado 201 I agosto]. Disponible en: http://www.inegi.org.mx 